\title{
Türkçe Öğretiminde Metin Türüne Uygun Okuma Eğitimi*
}

\author{
Reading Teaching Appropriate for Text Type in \\ Turkish Education
}

\author{
Şükran DiLIDÜZGÜN**, Zeynep ÇETINKAYA EDİZER*** \\ Duygu AK BAŞOĞUL $* * * *$, Melda KARAGÖZ*****
}

\begin{abstract}
Öz: Okuma; geçmişten günümüze seslendirme, anlama, kavrama ve yapılandırma ile ilişkilendirilerek tanımlanmıştır. Günümüzde ise okuma, üstbilişsel bir süreç olarak nitelendirilmekte ve bu süreci denetlemeyi temel almaktadır. Yetkin bir okurdan beklenen, belirli bir okuma amacıyla metne yaklaşıp okuma eylemi süresince artalan bilgilerini işe koşarak metne özgü yapıları anlamlandırabilmesidir. Bu yetkinlikler de metin türüne özgü üstbilişsel okuma stratejilerini işletmeyi gerektirir. Farklı üstbilişsel okuma stratejileri farklı okuma yöntem-teknikleriyle uygulanabilir. Bu bağlamda çalışmanın amacı, metin türlerine uygun üstbilişsel okuma sırası stratejileri ve okuma yöntem-tekniklerini ilişkilendirip etkinlik önerileri sunarak okuma eğitimi için ders araç-gereci gelişimine katkıda bulunmaktır. Yazınsal ve bilgilendirici metinlerin özelliklerini yansıtmaları ve ders kitaplarında sıklıkla kullanılmaları nedeniyle araştırmada, amaçlı örnekleme yöntemlerinden ölçüt örnekleme bağlamında öykü, şiir ve makale türleri ele alınmıştır. Betimsel bir araştırma olan çalışmada Dilidüzgün, Çetinkaya-Edizer, Ak-Başoğul, Karagöz ve Yücelşen (2018) tarafından hazırlanan metin türü bağlamında üstbilişsel okuma sırası stratejileri ile okuma yöntem-tekniklerinin ilişkilendirildiği çizelge kılavuz olarak seçilmiştir. Çalışma sonucunda araştırma kapsamına alınan üç metin türünün, okunma amacı doğrultusunda üstbilişsel okuma sırası stratejileri ile okuma yöntem-tekniklerinin kullanımı bağlamında ortaklıklar ve farklılaşmalar taşıdığı bulgulanmıştır. $\mathrm{Bu}$ ortaklık ve farklılaşmalar doğrultusunda belirtke tabloları hazırlanmış, etkinlikler belirtke tablolarından yola çıkılarak oluşturulmuştur. Oluşturulan bu etkinlikler, öneri niteliğinde olup uygulamalı çalışmalarla genellenebilirliğinin artırılacağı düşünülmektedir.
\end{abstract}

Anahtar Sözcükler: Türkçe öğretimi, okuma eğitimi, metin türü, üstbilişsel okuma stratejileri, okuma yöntem-teknikleri

\begin{abstract}
Reading; from past to present, is defined associated with the vocalisation, understanding, comprehension, and configuration. Today, reading is qualified as a metacognitive process and it is based on controlling this process. What is expected of a competent reader is that he/she can approach the text for a specific reading purpose and make sense of the text-specific structures by running background information during the reading action. These competencies also require the operation of metacognitive reading strategies specific to the text type. Different metacognitive reading strategies can be applied with different reading method-techniques. In this context, the aim of the study is to contribute to the development of materials for reading education presenting sample activities by linking metacognitive while reading strategies and reading method-techniques to the text types. Because of reflecting the characteristics of the literary and informative texts and being used frequently in the textbooks, the story, poem and article text types were taken in the context of criterion sampling from the purposive sampling methods. In this study, which is a descriptive research, a table relating metacognitive while reading strategies and reading method-techniques to the text type prepared by Dilidüzgün, Çetinkaya-Edizer, Ak-
\end{abstract}

\footnotetext{
* Bu çalışma 04-06 Ekim 2018 tarihlerinde Ankara'da gerçekleştirilen XI. Uluslararası Türkçenin Eğitimi-Öğretimi Kurultayında sözlü bildiri olarak sunulmuştur.

** Doç. Dr., İstanbul Üniversitesi-Cerrahpaşa, HAYEF, İstanbul-Türkiye, ORCID: 0000-0001-6627-8337, e-posta: sdilid@yahoo.com

*** Doç. Dr., İstanbul Üniversitesi-Cerrahpaşa, HAYEF, İstanbul-Türkiye, ORCID: 0000-0001-5449-5107, e-posta: cetinkayazeynep@gmail.com

**** Dr., İstanbul Üniversitesi-Cerrahpaşa, HAYEF, İstanbul-Türkiye, ORCID: 0000-0003-4065-2030, e-posta: duygu.akbasogul@istanbul.edu.tr

***** Dr., İstanbul Üniversitesi-Cerrahpaşa, HAYEF, İstanbul-Türkiye, ORCID: 0000-0001-9584-545X, e-posta: melda.karagoz@istanbul.edu.tr
} 
Başoğul, Karagöz and Yücelşen (2018) were selected as a guide. As a result of the study, it was found that the three text types within the scope of the research carried out similarities and differentiations in the context of the use of metacognitive while reading strategies and reading method-techniques in the direction of the purpose of reading. In accordance with these similarities and differentiations, tables of specification have been prepared and activities have been formed based on these tables of specification. These activities are considered as suggestions and it is thought that generalizability will be increased by applied studies.

Keywords: Turkish education, reading teaching, text type, metacognitive reading strategies, reading method-techniques

\section{Giriş}

Okumak; insanların dinlenme, eğlenme, bilgilenme, bir sorunu çözme vb. gereksinimleri sonucu gerçekleştirdikleri bir eylemdir. Demokratik toplumların gereksinim duyduğu düşünen-duyarlı bireylerin kazanması gereken en temel becerilerden biri okuma kültürüdür ve okuma kültürü edinmiş bireyler aynı zamanda yazılı kültürle dost olmuş bireylerdir (Sever, 2013). Bireylerin okuma kültürü kazanabilmesi, gereksinimlerini karşılarken haz almaları ve heyecan duymaları ile ilgilidir. Bu haz, okuma sürecindeki keşif ve buluşlarla duyumsanır. Bireylerin, okuma kültürü kazanabilmeleri için kurumsal bağlamda gerçekleştirilen okuma eğitiminde belleklerini devindiren, keşif ve buluşlara dayanan bir bilişsel süreç içine girebilmeleri önemlidir. Okuma eğitiminin farklı tanımlarıyla karşılaşılabilir; ancak okuma eğitimi, insanların farklı zamanlarda, farklı amaçlarını gerçekleştirebilmek için okumayı bir gereksinim olarak hissedebilmesini sağlama olarak tanımlanabilir. Bamberger (1990, s. 13) bunu, "okumaya olan yaklaşımın kişinin hayatı boyunca değişik türlerde ve farklı amaçlar için okuma yetisini koruyacak biçimde desteklenmesi, teşvik edilmesi” olarak ifade etmiştir.

Okuma, yalnızca sözcüklerin ifade edildiği bir kodu çözmek değil, dile dökülmüş düşünceleri çözümleme, yorumlama ve birleştirmeyi gerektiren üst düzey bilişsel bir süreçtir. $\mathrm{Bu}$ sürecin işletilmesinde üstbilişin etkin bir biçimde devindirilmesi gerekir. Üstbiliş, temelde bireyin nasıl öğreneceğini bilmesi ve bu süreci izleyebilmesidir (Flavell ve Wellman, 1977). Kişinin kendi düşünceleri hakkında bilgi ve farkındalık sahibi olmasını koşullayan üstbiliş; gereksinim duyulan bilgiyi elde etmek için bir strateji planlama, ilerlemenin farkında olma, problem çözme, derinlemesine düşünme ve kişisel düşüncelerin verimliliğini değerlendirme becerisidir (Aydın ve Atalay, 2015). Etkili bir okuma anlamanın gerçekleştirilmesi, okuma sürecinde üstbilişsel okuma stratejilerinin işletilmesini gerekli k1lar. Bireyin okuma amacına uygun olarak işletmesi gereken üstbilişsel okuma stratejilerini uygulayabileceği okuma yöntemtekniğiyle metni okuması gerekir. Ontario (2004), bilgilendirici metinlerin seçmeli, göz atarak, özetleyerek ve not alarak okunurken yazınsal metinlerin görsel, tahmin ederek, eleştirerek, metinlerle ilişkilendirerek okunduğunu belirtmektedir. Okuma amaçları, okurları belli metinsel bilgiye odaklanmaya ya da genel süreç stratejilerini benimsemeye iter (Bohn-Gettler ve Kendeou, 2014, s. 207). Bireyler okuma amaçları doğrultusunda farklı metin türlerine yönelirler; uygulayacakları okuma stratejilerini ise metnin yapısal özellikleri aracılığıyla işletirler. Shokouhi ve Jamali'nin de (2013, s. 128) araştırmalarında belirttikleri gibi metin türü, strateji seçimi konusunda etkilidir. Bu bakış açısı, Wellek ve Warren'ın da (1982, s. 317) metin türünün hem dışsal (yapı) hem de içsel (konu, amaç, seslenilen kitle vb.) biçim özelliklerine göre temellendirildiği görüşü ile uyum sağlamaktadır. Kısaca bireylerin farklı türdeki metinleri, gerektirdikleri üstbilişsel okuma stratejilerinin uygulanması için ortam yaratan farklı okuma yöntem-teknikleri ile okumaları gerekmektedir. $\mathrm{Bu}$ öğeler arasındaki ilişki Şekil 1'de görülmektedir:

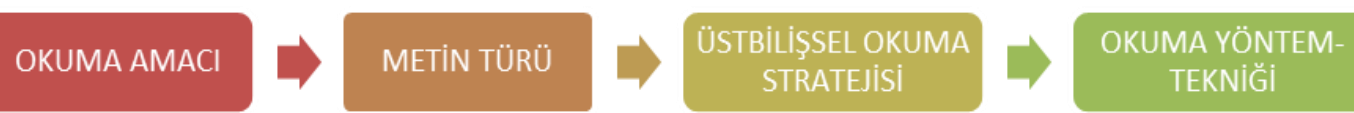

Şekil 1. Okuma Amac1, Metin Türü, Üstbilişsel Okuma Stratejisi ve Okuma Yöntem-Tekniği İlişkisi 
Erözden (1998), okumanın metin türlerinden doğrudan etkilenen bir ișlem olduğunu belirtmiştir. Belirli türleri okuma ve bunlar üzerinde çalışma, öğrencilerin tür bilgisiyle donanmış olmasını da gerektirir (Özdemir, 1993, s. 26). Metin türünün değişik örnekleriyle karşılaşan öğrenci, eski deneyimlerini anımsayarak metinlere önceki bilgileri doğrultusunda belli beklentilerle yaklaşacak, daha kısa sürede ve daha etkili anlama ve anlatma eylemlerini gerçekleştirebilecektir (Kim, 2006, s. 33-39). Öğrencilerin okuyacakları metin türüne belli beklentilerle yaklaşması ve uygun okuma stratejilerini işletebilmeleri olarak tanımlanabilen metin türü edincini geliştirmeleri gerekir (Paltridge, 2001). Grabe (2002, s. 252); Kucan ve Beck'in, anlatı ve açıllama metinleri ile yaptıkları çalışmada öğrencilerin türleri farklı yollarla okuduğunu bulguladıklarını belirtmiştir. Öğrenciler; anlatı metinlerinde varsayım, çıkarım, tahmin ve yorum yaparak önemli bilgileri belirlerken açıklama metinlerinde ise verilen bilgileri ayrıntıları ile anlamaya çalışmışlardır. Langer'ın (1990) yaptığı çalışmada ise öğrenciler, bilgi edinmeyi amaçladıkları metinlerde daha yoğun bir dikkat göstermiş ve konu ile ilgili kavramları eksiksiz biçimde anlamaya çalışmış olmalarına karşın yazınsal metinlerde olaylar ile duygular arasındaki etkileşime odaklanmış, betimlenen durumların işaret ettiği iletileri anlamaya çalışmışlardır.

Bilgilenimsel okuma, karmaşık yapısı olmayan; ancak alımlanması için okurdan düşünsel bir çaba bekleyen bir okuma biçimidir. Öğretici amacın öne geçtiği makale, deneme, köşe yazısı gibi türler bu okuma biçiminin kapsamındadır. Bilimsel ve öğretici nitelikteki metinlerin kendi okuma biçimine sahip olmasına benzer biçimde yazınsal ve kurmaca metinler de kendi yapılarına uygun okuma biçimi gerektirir (Özdemir, 1983). Edebiyatın işlevi, gerçeği yansıtmakla sınırlandırılamaz; okuru düşünsel ve duygusal yönden değiştirme, zenginleştirme, insanı bireysellikten kurtarıp başka insanların yaşayışları ile bütünleştirme görevi de vardır (Özdemir, 1993). Yazınsal anlatılarda, yazarın bulguladığı insanlık durumlarını somutlaştırdığı kurmaca evren tümüyle "dile dökülmüş" olarak verilmez; okur, söylenenden söylenmeyeni çıkararak yapıtın gerçekte neden söz ettiğini, neye ve nereye yöneldiğini kendi kafasında yazmak zorundadır. Yapıtın dünyası da kendisini alımlayanın dünyası ile bütünlenir; dolayısıyla eleştirel okuma kaçınılmazdır (Göktürk, 1989).

Okuma eğitiminin gerçekleştirildiği Türkçe derslerinde metin çalışmaları, öğrencileri metin türünün gerektirdiği üstbilişsel okuma stratejilerini işletmeyi olanaklı kılan okuma yöntem-tekniklerine yönlendirecek içerikte olmalıdır. Türkçe dersi öğretim programlarında ve Türkçe ders kitaplarında da okuma yöntem-tekniklerinin kullanımı üzerinde dikkatle durulduğu görülmektedir; ancak alanyazında gerçekleştirilen çalışmalara bakıldığında okuma yöntemteknikleri seçilirken metin türünün temel alınmadığı belirlenmiştir. Dilidüzgün (2013) tarafından yapılan çalışmada Türkçe ders kitabında okuma-anlama süreci etkinlikleri bilgilendirici ve öyküleyici metin türleri bağlamında incelendiğinde metin türü gözetilmeden benzer okuma-anlama etkinliklerinin gerçekleştirildiği ve metindeki önemli bilgileri bulma görevinin metin türü gözetilmeden "Anahtar kelimeleri, ana ve yardımcı düşünceleri bulunuz." gibi etkinliklerle süreç yaratmaktan çok sonuç üzerine odaklanıldığı görülmektedir. AydınGönül'ün (2016) Türkçe ders kitaplarındaki yazınsal metinleri okuma-anlama etkinliklerinin eleştirel okuma ölçütlerini karşılama yeterliğini sorguladığı çalışmasında da etkinliklerin eleştirel okumanın temel özelliği olan üst düzey bilişsel becerileri devindirmeye yönelik oluşturulmadığı sonucuna varılmıştır. Türkçe öğretiminde üstbilişsel okuma stratejileri ile okuma yöntem-tekniklerinin metin türüne göre değerlendirilmesi (Çetinkaya-Edizer, Dilidüzgün, Ak-Başoğul, Karagöz ve Yücelşen, 2018) adlı çalışmada da okuma sırasında işletilmesi gereken üstbilişsel okuma stratejilerinin okuma sonrasında uygulandığı, okuma yöntem-teknikleri ile üstbilişsel okuma stratejilerinin ilişkilendirilmediği, farklı metin türlerinde aynı okuma yöntem-teknikleri ile üstbilişsel okuma stratejilerinin kullanıldığı, ayrıca çok az sayıda üstbilişsel okuma stratejilerinin hedef alındığı bulgulanmıştır.

Okuma; okuma öncesi, sırası ve sonrası olarak üç aşamada gerçekleşir. "Okuma öncesinde kişi, konu ile ilgili ne öğreneceğine dair bir amaç ve onun etrafindaki öğrenme hedeflerini nasıl gerçekleştireceğini belirler" (Karatay, 2014, s. 42). Okuma sırasında okur, metni işlemlemeyle ilgili yeni stratejileri işe koşarak anlamlandırma düzeyini artırmaya çalışır 
(Ülper, 2010). Okuma sonrasında ise okur, metni anlamlama düzeyini değerlendirir. Okuma eğitiminin amac1; bireyin bireysel ve toplumsal gereksinimlerini karşılamak üzere başvurduğu metin türlerini anlayabilmesi ve yorumlayabilmesini sağlayacak üstbilişsel okuma stratejilerini işletebilecek yetiyi kazandırmaktır. Örneğin; okuma sırasında işe koşulan stratejilerden yola çıkılarak öykünün iletisi çıkarılır (Ontario, 2004, s. 90). Bu amaç doğrultusunda bu araştırma, öncelikle anlamlandırma aşaması olarak da adlandırılan üstbilişsel okuma sırası stratejilerini temel almaktadır. Araştırmanın amacı, metin türlerine özgü üstbilişsel okuma sırası stratejileri ile okuma yöntem-tekniklerini ilişkilendirerek üstbilişsel okuma sırası stratejilerini kazandırmaya yönelik okuma yöntem-tekniklerini gerektiren etkinlik önerileri sunmaktır.

\section{Yöntem}

Bu çalışma; verileri, doğal ortamdan derleyip bütüncül ve derinlemesine bir anlayışla ele alması, araştırmacıyı temel veri toplama aracı olarak görmesi bakımından nitel ve betimsel bir araştırmadır (Creswell, 2014, s. 185-186).

\section{Araștırma süreci}

Metin türlerine yönelik üstbilişsel okuma sırası stratejilerini işletebilecek okuma yöntemtekniklerine uygun etkinlik önerileri sunmayı amaçlayan bu araştırmada; Dilidüzgün, Çetinkaya-Edizer, Ak-Başoğul, Karagöz ve Yücelşen (2018) tarafından hazırlanan metin türü bağlamında üstbilişsel okuma sırası stratejileri ile okuma yöntem-tekniklerinin ilişkilendirildiği çizelge, kılavuz olarak seçilmiştir. Çizelgede, alanyazından yola çıkarak belirlenen 28 üstbilişsel okuma sırası stratejisi ile 14 okuma yöntem-tekniği, metin türleri odağında sınıflandırılmış ve hangi metin türünün hangi üstbilişsel okuma sırası stratejileri ile okuma yöntem-tekniklerini işletmeyi gerektirdiği, 4 alan uzmanının görüşleri de alınarak belirlenmiştir.

Özdemir (1992, s. 39), ilköğretim Türkçe derslerinde öğretici/bilgilendirici ve yaşatıcı/yaşantı kazandırıcı (yazınsal) türler olarak iki temel tür üzerine odaklanıldığını vurgulamıştır. Metin türü temelli okuma türleri de yazınsal metinleri okuma ve bilgilendirici metinleri okuma olarak iki ana başlık altında gösterilmektedir (Ülper, 2010). Türkçe Dersi Öğretim Programı'nda ise (MEB, 2018, s. 20) öyküleyici, bilgilendirici ve şiir türlerinin temel alındığı görülmüştür. Sıralanan metin tiplerinin özelliklerini yansıtmaları ve ders kitaplarında sıklıkla kullanılmaları nedeniyle de araştırmada, amaçlı örnekleme yöntemlerinden ölçüt örnekleme benimsenerek öykü, şiir, makale türleri üzerine odaklanılmıştır.

Araştırma kapsamında öncelikle öykü, şiir ve makale türlerinin özelliklerinin ve ayrımlarının belirlenmesi için alanyazın taraması yapılmıştır. Ardından her tür için ders kitaplarından birer metin seçilmiş ve okuma amacına göre metin türlerinin oluştuğu, her türün de belli bir metin yapısına sahip olduğu görüşünden yola çıkarak metindilbilim odaklı etkinlikler hazırlanmıştır. Söz konusu metinlere özgü etkinlikler geliştirilirken, kılavuz olarak seçilen çizelgede belirtilen öykü, şiir ve makale türlerine uygun üstbilişsel okuma stratejileri ile ilişkili olan okuma yöntem-teknikleri ve Bloom'un yenilenmiş taksonomisi (Anderson ve diğerleri, 2014) temel alınmıştır. Etkinliklerin; soyut tanımlamalardan çok, metinler içinde geçen dil öğelerinden örnekler verilerek ya da bu dil öğelerinin kullanılmasını gerekli kılan çalışmalar olarak düzenlenmesine önem verilmiştir. Her etkinliğin ilişkili olduğu üstbilişsel okuma sırası stratejileri ile okuma yöntem-tekniklerini gösteren belirtke tabloları oluşturulmuş; bu tablolar ve etkinlikler 3 alan uzmanı, 1 ölçme-değerlendirme uzmanı ve 1 Türkçe öğretmenine gönderilerek görüşlerine başvurulmuştur. Gelen değerlendirmeler doğrultusunda gerekli düzenlemeler yapılmıştır.

Belirtke tablolarının geçerliği ve güvenirliğini artırmak amacıyla çalışma kapsamındaki metin türlerinin farklı örnekleri için, tablolar doğrultusunda, yine ders kitaplarından seçilen farklı ikişer metin üzerine de aynı yaklaşım ve çizelge doğrultusunda yeni etkinlikler üretilmiştir. Dolayısıyla türe özgü etkinlikler, üçer metin odaklı olarak hazırlanmıştır. Bu yinelemeli uygulamalardan yola çıkarak hazırlanan etkinlikler ile tabloların uyumlu olduğu sonucuna varılmıştır. Böylelikle belirtke tablolarının geçerlik ve güvenirlik işlemleri de tamamlanmıştır. Ardından metinlerin işlenmesi için hazırlanan etkinlikler, metin türlerine özgü 
üstbilişsel okuma sırası stratejileri üst başlığı ve okuma yöntem-teknikleri alt başlığı altında sınıflandırılmıştır.

\section{Bulgular}

Araştırmanın bu bölümünde öykü, şiir ve makale türlerine ilişkin bulgular, türlere özgü "üstbilişsel okuma sırası stratejileri ile okuma yöntem-tekniklerinin ilişkilendirilmesi” ve "üstbilişsel okuma sırası stratejilerini kazandırmaya yönelik okuma yöntem-tekniklerini gerektiren etkinlik önerileri” başlıkları altında verilecektir.

\section{Öykü türüne yönelik bulgular}

\section{Öykü türüne özgü üstbilişsel okuma strası stratejileri ile okuma yöntem-tekniklerinin ilişkilendirilmesi}

Öykü türü için üstbilişsel okuma sırası stratejilerinin kullanımında sırasıyla eleştirel, metinlerle ilişkilendirme, tahmin ederek ve özetleyerek okuma yöntemlerinin uygulandığ görülmektedir (bk. Tablo 1). Öykünün konu ve iletisi yapılandırıldıktan sonra yaratıcı okuma ortamı doğmakta, görsellerle sunulan öykülerde ise görsel okuma yöntemi kullanılmaktadır.

Tablo 1.

Öykü Türüne Özgü Üstbilişsel Okuma Sırası Stratejilerini Karşılayan Okuma YöntemTeknikleri

Öykü Türüne Özgü Üstbilişsel Okuma Sırası Stratejileri

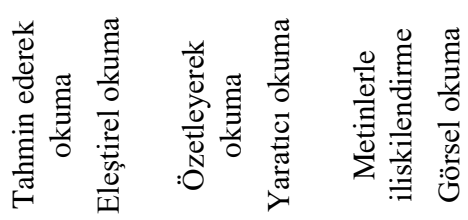

Bilinmeyen sözcüklerin anlamını bulma

Metindeki grafik, tablo ve resim gibi kavramlardan yararlanma

Zaman zaman durarak okuduklarını denetleme

Bağlama yönelik ipuçlarını kullanma

Anlamı bilinmeyen sözcük ve sözcük öbeklerini bağlam içinde

tahmin etmeye çalışma

Dilbilgisel ilişkileri kestirme/Bağlayıcıları tanıma

Sözcükleri parçalama

Sözcükleri sinıflandırma

Sözcükleri ilişkilendirme

Etkinleştirilen biçimsel şemadan/tür bilgisinden yararlanma

Yeni bilgilerle önceki bilgileri ilişkilendirme, çağrışım oluşturma

Yazınsal araçlar ya da retorik stratejiler gibi metne özgü özellikleri tanıma

Gösterimsel imge oluşturma

\begin{tabular}{llllll}
$\mathrm{X}$ & $\mathrm{X}$ & & & $\mathrm{X}$ & \\
& $\mathrm{X}$ & & & $\mathrm{X}$ & $\mathrm{X}$ \\
& $\mathrm{X}$ & $\mathrm{X}$ & & & \\
$\mathrm{X}$ & $\mathrm{X}$ & $\mathrm{X}$ & $\mathrm{X}$ & & \\
$\mathrm{X}$ & $\mathrm{X}$ & & & $\mathrm{X}$ & \\
& & & & & \\
$\mathrm{X}$ & $\mathrm{X}$ & $\mathrm{X}$ & & & \\
& $\mathrm{X}$ & & & & \\
& $\mathrm{X}$ & & & $\mathrm{X}$ & \\
$\mathrm{X}$ & $\mathrm{X}$ & $\mathrm{X}$ & & $\mathrm{X}$ & \\
$\mathrm{X}$ & $\mathrm{X}$ & $\mathrm{X}$ & $\mathrm{X}$ & & $\mathrm{X}$ \\
$\mathrm{X}$ & $\mathrm{X}$ & & $\mathrm{X}$ & $\mathrm{X}$ & \\
& $\mathrm{X}$ & $\mathrm{X}$ & & $\mathrm{X}$ & \\
& & & & & \\
& $\mathrm{X}$ & & $\mathrm{X}$ & & \\
\hline
\end{tabular}

Öykü türüne özgü üstbilişsel okuma sırası stratejilerini kazandırmaya yönelik okuma yöntemtekniklerini gerektiren etkinlik önerileri

Bilinmeyen sözcüklerin anlamını bulma

- Tahmin ederek okuma etkinlikleri: Metinde geçen sözcükleri görselleriyle eşleştirme.

- Eleştirel okuma etkinlikleri: Anlamı bilinmeyen sözcüklerle sözcük öbeği oluşturmak için tüm sınıfa karışık olarak dağıtılan kağıtlardan hangilerinin anlamı bilinmeyen sözcüklerle birleşerek sözcük öbeği oluşturabileceğine karar verme; anlamı bilinmeyen sözcükleri birlikte kullanıldıkları sözcüklerle eşleştirme.

- Metinlerle ilişkilendirme etkinlikleri: Bilinmeyen sözcüğe ya da deyimi oluşturan sözcüklerin anlamına sözlükten bakarak tahminlerin doğru olup olmadığına karar verme. 
Metindeki grafik, tablo ve resim gibi kavramlardan yararlanma

- Eleştirel okuma etkinlikleri: Görselin öyküye uygunluğunu değerlendirme ve önerilerde bulunma.

- Metinlerle ilişkilendirme etkinlikleri: Öyküdeki görsellerle öyküde yer alan kişi ve yer betimlemelerini karşılaştırma.

- Görsel okuma etkinlikleri: Öykünün görsellerine bakarak öyküdeki kişileri ve olayları tasarlama; öyküyü okuduktan sonra tahminleriyle ilgili değerlendirmede bulunup görseli eleştirme.

\section{Zaman zaman durarak okuduklarını denetleme}

- Eleştirel okuma etkinlikleri: Öykünün belli bölümlerinde kahraman için kullanılan ad ve sıfatları belirleme; bölümler arasındaki farklılık ve benzerlikleri bulma; öyküdeki kahramanların bazı kavramlar ve olaydaki diğer kahramanlar hakkındaki değer yargılarını ve düşüncelerini belirleme.

- Özetleyerek okuma etkinlikleri: Öykünün konusu ve olaylarla ilgili tahminleri değerlendirme; olayların ne olduğu, kimler arasında ne zaman ve nerede geçtiğini saptayarak öykü haritasını doldurma; öykü içinde verilen sorulardan hangisinin yanıtının olmadığını bulma.

\section{Bağlama yönelik ipuçlarını kullanma}

- Tahmin ederek okuma etkinlikleri: Öyküdeki betimlemelerden yola çıkarak bir yer ve kişi için kullanılan bir sözcügün hangi anlamları kapsayabileceğini ya da hangi anlama geleceğini tahmin etme; öykü içinde yalnız baş harfleri verilmiş sözcükleri tahmin etme.

- Eleştirel okuma etkinlikleri: Öyküdeki betimlemelerden yola çıkarak yazarın olaya ve özellikle de olayın kahramanlarına karşı tavrını saptama; öykü kişilerinden birinin yerine geçerek olayların nasıl değerlendirildiği, bazı sorular karşısında ne yanıt verileceği ve nasıl davranılacağı konusundaki soruları yanıtlama.

- Özetleyerek okuma etkinlikleri: Olaylar ve kişiler hakkında verilen bilgilere bakarak öyküdeki bazı olayların nedenlerini kestirme.

- Yaratıcı okuma etkinlikleri: Öyküde, nesneler-kişiler ya da kişiler-kişiler arasında geçen bir konuşmayı tamamlama.

\section{Anlamı bilinmeyen sözcük ve sözcük öbeklerini bağlam içinde tahmin etme}

- Tahmin ederek okuma etkinlikleri: Tümcenin anlamı değişmeyecek şekilde hedef sözcüğün ya da deyimin yerine konulabilecek ya da konulamayacak sözcükleri seçme ya da bulma.

- Eleştirel okuma etkinlikleri: Sözcügün metinde geçtiği tümceyi vererek farklı anlamlarından metinde kullanılan anlamını seçme ya da farklı sözcüklerin anlamları arasından doğru anlamı seçme; verilen eylemin çok yönlü işlevlerini ayırt etme.

- Metinlerle ilişkilendirme etkinlikleri: Sözcüğün aynı anlamda kullanıldığı ya da kullanılmadığı tümceyi ayırt etme; öyküde kullanılan bazı sözcüklerle farklı tümcelerdeki boşlukları doldurma ve tanımlarıyla eşleştirme.

\section{Dilbilgisel ilişkileri kestirme/Băglayıcıları tanıma}

- Tahmin ederek okuma etkinlikleri: Öyküde yineleme yapılan sözcüklerden yola çıkarak anahtar sözcükleri ve iletiyi tahmin etme.

- Eleştirel okuma etkinlikleri: Öyküde kullanılan belirlilik ve belirsizlik nitelemeleri, küçültme sıfatları vb. kullanımları anlamlandırma; öyküde kullanılan eylemler ve eylem zamanlarını belirleme ve gruplandırma; öyküde kullanılan sözcüklerden birbirleriyle bağdaşmayanları ayırt etme; öyküde kullanılan anahtar sözcüklerin eş/yakın anlamlılarını ve öykünün hangi bölümünde yoğunluk kazandıklarını belirleme; öykü 
içindeki neden-sonuç ilişkilerini ayırt etme; öyküde kullanılan zaman belirteçlerini olaylarla eşleştirme.

- Özetleyerek okuma etkinlikleri: Verilen sözcükleri, tümceleri ya da bağlayıc1ları kullanarak öyküyü özetleme.

\section{Sözcükleri parçalama}

- Eleştirel okuma etkinlikleri: Metinde farklı zamanlarda çekimlenmiş yüklemlerden oluşan tümceleri olay (görülen geçmiş zaman) / betimleme (şimdiki zamanın hikayesi) olarak gruplandırma; öyküdeki ad ve eylem tümcelerini ayırt etme.

\section{Sözcükleri sinıflandırma}

- Eleştirel okuma etkinlikleri: Öykü kişileri için kullanılan adları, niteleyicileri, geçen olayları ve kişilerin yaptıkları eylemleri sınıflandırma.

- Metinlerle ilişkilendirme etkinlikleri: Öyküde geçen adlar için hangi niteleyicilerin kullanıldığını saptama; bu niteleyicilerin anlama kattığı değeri sorgulama ve yerine hangi niteleyicilerin kullanılıp kullanılamayacağını tartışma.

\section{Sözcükleri iliş̧kilendirme}

- Tahmin ederek okuma etkinlikleri: Başl1kta yer alan sözcüklerin kavram alanlarından ve anlam değerlerinden yola çıkarak öykünün konusunu tahmin etme.

- Eleştirel okuma etkinlikleri: Öyküde geçen nesnelerin nerede yer alıp alamayacağını belirleme.

- Özetleyerek okuma etkinlikleri: Öyküde kişilerin hangi özelliklerinden söz edilip edilmediğini bulma; anahtar sözcükleri temel alarak öykünün iletisini belirleme.

- Metinlerle ilişkilendirme etkinlikleri: Olay ve öykünün sonucu ile başlığı arasında ilişki kurma ve başlıktaki sözcükleri anlamlandırma; öykünün iletisiyle ilgili verilen tümcelerde öykünün ana izleği ile ilgili sözcüklerin altını çizme.

\section{Etkinleştirilen biçimsel şemadan/tür bilgisinden yararlanma}

- Tahmin ederek okuma etkinlikleri: Öykünün dügüm bölümünde olaydaki kişilerin düşündüklerini tahmin etme; çatışmanın nasıl çözüldüğü hakkında tahminde bulunma.

- Elesstirel okuma etkinlikleri: Öykünün son bölümünde yazarın kimlere, ne amaçla seslendiğini belirleme; öykünün sonunda yazarın kahraman için kullandığı sözcüklerin metni bölümlere ayırma ve iletiyi belirlemedeki işlevini sorgulama; verilen tümcelerden öykünün iletisi ile ilgili olanları işaretleme.

- Özetleyerek okuma etkinlikleri: Öyküde ne anlatıldığını (olay, durum, kişi) saptama; öyküde sırasıyla anlatılan ve karışık olarak verilen konu başlıklarını doğru sıraya koyma; verilen öykü üstyapı kategori tanımlarına göre öyküyü bölümlere ayırma; öykünün üstyapı kategorilerinin bulunduğu tabloyu öyküye göre doldurma; öyküden verilen tümcelerin öykünün hangi üstyapı kategorisine ait olduğunu bulma.

- Yaratıcı okuma etkinlikleri: Öyküye türüne uygun olarak farklı bir başlık bulma; öykünün iletisiyle ilgili farklı tümceler kurma.

- Görsel okuma etkinlikleri: Yazarın kahraman için kullandığı yinelemeleri, yineleme zincirine yazma; benzerlik gösteren bölümleri renklendirerek öykünün üstyapı şemasına ulaşma ve bu şemadan yola çıkarak öyküyü özetleme.

Yeni bilgilerle önceki bilgileri ilişkilendirme, çă̆rışım oluşturma

- Tahmin ederek okuma etkinlikleri: Metinde sözü edilen nesne, kişi, konuşma vb. nerede ya da hangi durumda karşıllaşabileceğini tahmin etme; sözü edilen çeşitli yerlerde başka neler olabileceğini tahmin etme.

- Eleştirel okuma etkinlikleri: Öyküde geçen kişi ve yaşamı daha iyi çözümleyebilmek için günlük yaşamdaki örnekleriyle karşılaştırma. 
- Yaratıcı okuma etkinlikleri: Öyküde yaşanan durumla benzerlik taşıyan başka örnekler verme; öyküde geçen yer ve kişiler için uygun betimlemeler üretme.

- Metinlerle ilişkilendirme etkinlikleri: Öykünün konusunda yer alan bazı olgularla (meslek, kurum, yer vb.) ilgili bilgileri, öykü okunmadan önceki iletiye yönelik tahminleri doğrultusunda irdeleme ve işlevlerini eşleştirme.

Yazınsal araçlar ya da retorik stratejiler gibi metne özgü özellikleri tanıma

- Eleştirel okuma etkinlikleri: Öyküde yapılan benzetmeleri bulma; yapılan karşılaş̧ırmalardaki benzerlik ve farklılıkları bulma; öykü içinde verilen tümcelerden içerisinde kişileştirme yapılanları seçme; verilen bilgiler ışı̆̆ında kahramanın geliştirilme yöntemini belirleme.

- Özetleyerek okuma etkinlikleri: Metinde kişilerin duygusal durumları ve tutumları için kullanılan dil öğelerinden yola çıkarak olayların nedenleri hakkında tahminde bulunma.

- Metinlerle ilişkilendirme etkinlikleri: Öyküde yapılan benzetmeleri değerlendirme ve anlamlandırma (çoklu seçenekler içinden seçme); yapılan söz sanatlarının metne kattığ anlamı tartışma; öyküde yapılan benzetmeleri günlük yaşamdaki olaylarla bağdaştırma.

\section{Gösterimsel imge oluşturma}

- Eleştirel okuma etkinlikleri: Öyküde betimlenen ortam ile kişiler, olaylar ve iletiyi ilişkilendirme ve yorumlama.

- Yaratıcı okuma etkinlikleri: Öyküde anlama katkı sağlayan bir betimlemeye göre yarım bırakılan görseli tamamlama; gruplar oluşturarak öykü için kapak resmi canlandırma veya tasarlama.

\section{Şiir türüne yönelik bulgular}

Şiir türüne özgü üstbilişsel okuma sırast stratejileri ile okuma yöntem-tekniklerinin ilişkilendirilmesi

Şiir türü için üstbilişsel okuma sırası stratejilerinin kullanımında daha çok eleştirel okuma yönteminin kullanıldığ görülmektedir (bk. Tablo 2). Bu tür için esnek, yaratıcı ve metinlerle ilişkilendirme yöntemleri de kullanılmaktadır.

Tablo 2.

Şiir Türüne Özgü Üstbilişsel Okuma Sırası Stratejilerini Karşılayan Okuma Yöntem-Teknikleri

Şiir Türüne Özgü Üstbilişsel Okuma Sırası Stratejileri

\begin{tabular}{|c|c|c|c|}
\hline 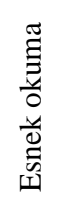 & 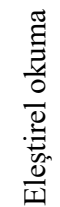 & 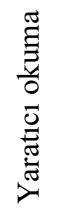 & 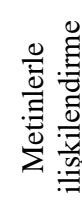 \\
\hline$X$ & $\begin{array}{l}\mathrm{X} \\
\mathrm{X} \\
\mathrm{X} \\
\mathrm{X}\end{array}$ & & $X$ \\
\hline X & $\begin{array}{l}\mathrm{X} \\
\mathrm{X} \\
\mathrm{X} \\
\mathrm{X}\end{array}$ & $\begin{array}{l}X \\
X\end{array}$ & $X$ \\
\hline
\end{tabular}




\section{Şiir türüne özgü üstbilişsel okuma sırası stratejilerini kazandırmaya yönelik okuma yöntem- tekniklerini gerektiren etkinlik örnekleri \\ Bilinmeyen sözcüklerin anlamını bulma}

- Eleştirel okuma etkinlikleri: Sözcükleri ve anlamları eşleştirme; şiirdeki bir sözcügün anlamını, verilen tanımlar içerisinden seçme; dizeleri düzyazıya çevirme; şiirdeki bir sözcükle ilgili verilen tümcelerin içinden sözcüğün anlamını veren tümceyi seçme.

\section{Zaman zaman durarak okuduklarını denetleme}

- Eleştirel okuma etkinlikleri: Dizelerde anlatılmak istenen anlamı yanına yazma; şiirde yer verilen duyguları belirleme; şiirdeki ana duyguyu oluşturan bir sözcügün neyi ifade ettiğini belirleme.

\section{Bağlama yönelik ipuçlarını kullanma}

- Eleștirel okuma etkinlikleri: Şiirin her bir bölümünde anlatılmak istenenleri açılama; şiirdeki bir dizenin anlamından yola çıkarak özellikler belirleme; şiirdeki bir ifadeyle kast edilen duyguyu belirleme; şiirdeki anahtar sözcükleri birleştirerek tümce yazma; şiirin amacını belirleme; şiirin konusunu belirleme; şiirin ana duygusunu belirleme; şiirden yola çıkarak şairin sanata bakış açısını belirleme; şiirden yola çıkarak bir olguyu tanımlama; şiirde söz edilen yerleri görsellerle eşleştirme; şiirde birbiriyle benzer olan ifadeleri eşleştirme.

- Esnek okuma etkinlikleri: Şiirdeki anahtar sözcüklerin altını çizme.

- Metinlerle iliş̧kilendirme etkinlikleri: Şiirdeki ana duyguyla benzer olan şiirleri seçme.

Anlamı bilinmeyen sözcük ve sözcük öbeklerini bağlam içinde tahmin etmeye çalışma

- Eleştirel okuma etkinlikleri: Şiirde yer alan deyim ya da atasözüyle aynı anlamda olan deyim ya da atasözünü belirleme; şiirde kullanılan zit anlamdaki sözcüklerle anlatılmak istenenleri belirleme; dizede yer alan bir sözcüğün ne anlam ifade ettiğini belirleme; şiirdeki bir sözcügün anlamına uygun olan tümceyi seçme; dizede yer alan bir sözcügün yerine aynı anlamı karşılayacak sözcüğü yazma.

\section{Dilbilgisel ilişkileri kestirme/Bă̆layıcıları tanıma}

- Eleştirel okuma etkinlikleri: Şiirdeki bağlaçların altını çizme ve tümceye kattığı anlamı bulma; şiirdeki bağlaçları değiştirerek aynı anlamı karşılayan yeni tümceler yazma; şiirde yer alan ikilemeyle eş görevde olan ikileme örnekleri verme; şiirde yer alan benzetmeyle eş görevde olan benzetme örnekleri verme; şairin öznel ifadelerini belirleme; şairin seçtiği anlatıcı tipinin işlevini belirleme.

\section{Sözcükleri parçalama}

- Eleştirel okuma etkinlikleri: Şiirde yer alan bir ekle eş görevde olan sözcüğü belirleme; şiirde yer alan belirli sözcüklerin kökünü belirleyerek sözcügün anlamını çokanlamlılık açısından belirleme.

\section{Sözcükleri sinıflandırma}

- Eleştirel okuma etkinlikleri: Metinde geçen deyime anlamca yakın olan deyimleri belirleme; metinde geçen bir sözcüğün anlamını, sözcüğün taşıdığ 1 diğer anlamların içerisinden seçme; şiirden dizeler vererek farklı duygular yansıtanları belirleme.

\section{Sözcükleri ilişkilendirme}

- Eleştirel okuma etkinlikleri: Şiirde ele alınan konuyla ilgili olan/olmayan sözcükleri bulma; şiirde en çok kullanılan sözcükleri belirleme; şiirde geçen belirli sözcüklerle duyguları eşleştirme; şiirdeki ana duygu için kullanılabilecek/kullanılamayacak sözcükleri/sıfatları seçme. 
Etkinleştirilen biçimsel şemadan/tür bilgisinden yararlanma

- Esnek okuma etkinlikleri: Şiirin biçim özellikleriyle ilgili olan/olmayan ifadeleri seçme; okunan şiir çerçevesinde bir şiir yazılacak olsa biçimsel açıdan hangi özelliklerin kullanılacağını belirleme.

Yeni bilgilerle önceki bilgileri ilişkilendirme, çağrışım oluşturma

- Metinlerle ilişkilendirme etkinlikleri: Şairin şiirde belirttiği ifadelere uygun olabilecek şiirleri, türküleri, fablları vb. seçme.

- Yaratıcı okuma etkinlikleri: Şiirde ele alınan konuyla ilgili önceki bilgilerini de içeren bir tanıtım yazısı yazma; şiirde ele alınan ana duygu çerçevesinde farklı bir konuda şiir yazma.

Yazınsal araçlar ya da retorik stratejiler gibi metne özgü özellikleri tanıma

- Eleştirel okuma etkinlikleri: Okunan şiir çerçevesinde bir şiir yazılacak olsa hangi duygulardan yararlanılacağını belirleme; şiirde yer alan söz sanatına uygun örnekler verme; şairin şiiri oluştururken konunun hangi özelliklerinden yararlandığını belirleme; şiirin türünü örnekler vererek açıklama; şiirde kullanılan anlatım özelliklerini belirleme; şairin şiiri oluştururken yararlandığı anlatım yollarını örneklerle açıklama.

Gösterimsel imge oluşturma

- Yaratıcı okuma etkinlikleri: Şiirdeki imgeli anlatımı kullanarak kendi ifadeleriyle yeni bir şiir oluşturma; şiirdeki ana duygu çerçevesinde betimsel bir paragraf yazma; şiirdeki anlatıma uygun imgesel bir başl1k yazma.

\section{Makale türüne yönelik bulgular}

Makale türüne özgü üstbilişsel okuma strası stratejileri ile okuma yöntem-tekniklerinin ilişkilendirilmesi

Makale türüne özgü üstbilişsel okuma sırası stratejilerinin geliştirilmesi sürecinde; eleştirel, esnek, işaretleyerek ve seçmeli okuma yöntem-teknikleri üzerinde yoğunlaşıldığı görülmektedir (bk. Tablo 3).

Tablo 3.

Makale Türüne Özgü Üstbilişsel Okuma Sırası Stratejilerini Karşılayan Okuma YöntemTeknikleri

\begin{tabular}{|c|c|c|c|c|c|c|c|c|c|}
\hline Makale Türüne Özgü Üstbilişsel Okuma Sırası Stratejileri & 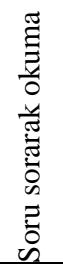 & 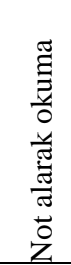 & 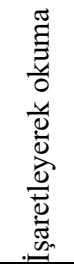 & 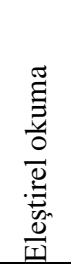 & 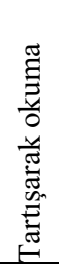 & 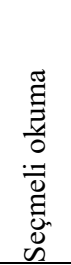 & 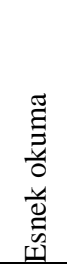 & 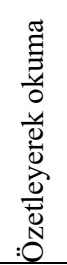 & 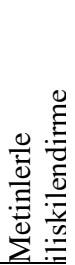 \\
\hline Bilinmeyen sözcüklerin anlamını bulma & & & & & & $\mathrm{X}$ & & & \\
\hline Okurken not tutma & & $\mathrm{X}$ & $\mathrm{X}$ & & & $\mathrm{X}$ & $\mathrm{X}$ & & \\
\hline $\begin{array}{l}\text { Anladığından emin olmak için yavaş fakat dikkatli } \\
\text { okuma/Okuma amacına uygun bir okuma hızıyla okuma, } \\
\text { okuma hızını ayarlama }\end{array}$ & & & $\mathrm{X}$ & & & $\mathrm{X}$ & $\mathrm{X}$ & & \\
\hline $\begin{array}{l}\text { Önemli bilginin ve/veya anahtar noktaların altını çizme } \\
\text { veya yuvarlak içine alma }\end{array}$ & & & $\mathrm{X}$ & & & $\mathrm{X}$ & $X$ & & \\
\hline $\begin{array}{l}\text { Anlamayı artırmak için sözlük, genel ağ gibi başvuru } \\
\text { kaynaklarını kullanma }\end{array}$ & & $\mathrm{X}$ & & & & & & & $\mathrm{X}$ \\
\hline Metin zor geldiğinde üzerinde iyice yoğunlaşma & & & & $\mathrm{X}$ & & & $\mathrm{X}$ & & \\
\hline Okuduğunu kavramaya yardımcı olması için gerekirse & & & $\mathrm{X}$ & & & $\mathrm{X}$ & $\mathrm{X}$ & & \\
\hline
\end{tabular}


yüksek sesle okuma

\begin{tabular}{|c|c|c|c|c|c|c|c|}
\hline Zaman zaman durarak okuduklarını denetleme & & & $\mathrm{X}$ & & & $\mathrm{X}$ & \\
\hline Bağlama yönelik ipuçlarını kullanma & & & $\mathrm{X}$ & & & $\mathrm{X}$ & \\
\hline $\begin{array}{l}\text { Bilginin akılda kalıcılığını sağlamak için onu şema, resim } \\
\text { gibi görsellerle formülleştirme }\end{array}$ & & & $\mathrm{X}$ & & & & \\
\hline $\begin{array}{l}\text { Noktalama işaretlerine, kalın ve italik yazımlara dikkat } \\
\text { etme }\end{array}$ & & & & $X$ & & & \\
\hline $\begin{array}{l}\text { Metinde çelişkili bir bilgiyle karşılaşınca metni tekrar } \\
\text { gözden geçirme }\end{array}$ & & & $\mathrm{X}$ & & & $\mathrm{X}$ & \\
\hline $\begin{array}{l}\text { Anlamı bilinmeyen sözcük ve sözcük öbeklerini bağlam } \\
\text { içinde tahmin etmeye çalışma }\end{array}$ & & & $\mathrm{X}$ & & $\mathrm{X}$ & & \\
\hline $\begin{array}{l}\text { Metinde geçen karmaşık fakat önemli bilgi ve } \\
\text { düşünceleri ayırt etme/özetleme }\end{array}$ & & $\mathrm{X}$ & $\mathrm{X}$ & & & $\mathrm{X}$ & $\mathrm{X}$ \\
\hline Dilbilgisel ilişkileri kestirme/Bağlayıcıları tanıma & & & $\mathrm{X}$ & & & & \\
\hline Sözcükleri parçalama & & & $\mathrm{X}$ & & & & \\
\hline Sözcükleri sınıflandırma & & $\mathrm{X}$ & $\mathrm{X}$ & & & & \\
\hline Sözcükleri ilişkilendirme & & $\mathrm{X}$ & & $\mathrm{X}$ & & & \\
\hline $\begin{array}{l}\text { Etkinleştirilen biçimsel şemadan/tür bilgisinden } \\
\text { yararlanma }\end{array}$ & $\mathrm{X}$ & $\mathrm{X}$ & $\mathrm{X}$ & & $\mathrm{X}$ & $\mathrm{X}$ & $\mathrm{X}$ \\
\hline $\begin{array}{l}\text { Metinle ilgili önceki sorularını yeniden inceleme ve } \\
\text { düzeltme }\end{array}$ & $X$ & & & & & & \\
\hline $\begin{array}{l}\text { Metindeki önemli bilgilere diğer bilgilerden daha çok } \\
\text { dikkat kesilme veya ileriye ya da geriye dönük sıçramalar } \\
\text { yapma }\end{array}$ & & $\mathrm{X}$ & $\mathrm{X}$ & & $\mathrm{X}$ & $\mathrm{X}$ & \\
\hline Her bir paragrafin ana fikrini tahmin etme & & & $\mathrm{X}$ & & $\mathrm{X}$ & & $\mathrm{X}$ \\
\hline $\begin{array}{l}\text { Yeni bilgilerle önceki bilgileri ilişkilendirme, çağrışım } \\
\text { oluşturma }\end{array}$ & & & $\mathrm{X}$ & & & & \\
\hline $\begin{array}{l}\text { Başlık, okuma ilerledikçe alt başlık, görsel çizimler vb. } \\
\text { öğelerden yararlanarak metnin iletisini kestirme ve } \\
\text { onaylama }\end{array}$ & & & $\mathrm{X}$ & & & & \\
\hline Okuduklarını arkadaşlarıyla tartışma & $X$ & & $\mathrm{X}$ & $\mathrm{X}$ & & & \\
\hline
\end{tabular}

Makale türüne özgü üstbilişsel okuma sırası stratejilerini kazandırmaya yönelik okuma yöntem-tekniklerini gerektiren etkinlik örnekleri

Bilinmeyen sözcüklerin anlamını bulma

- Seçmeli okuma etkinlikleri: Sözcükleri anlamlarıla eşleştirme; sözlük vb. başvuru kaynaklarından yararlanarak bilinmeyen sözcügün anlamını bulma.

\section{Okurken not tutma}

- Işsaretleyerek okuma etkinlikleri: Metinden yola çıkarak anahtar sözcüklerle ilişkili sözcükleri bulma.

- Not alarak okuma etkinlikleri: Anahtar sözcüğün, makalede sözü edilen işlevlerini listeleme; makalenin konusunu yazma.

- Esnek okuma etkinlikleri: Makalenin yazılış amacını kestirme; makale türüne özgü kullanımları belirleme.

- Seçmeli okuma etkinlikleri: Makalede ileri sürülen tez, görüş, inanç ve varsayımları saptama; makalede ileri sürülen tez, görüş, inanç ve varsayımların kim tarafindan savunulduğunu belirleme; makalede ileri sürülen tez, görüş, inanç ve varsayımların sunuluş biçimlerini ve geliştirilme yollarını belirleme.

Anladı̆̆ından emin olmak için yavaş fakat dikkatli okuma/Okuma amacına uygun bir okuma hızıyla okuma, okuma hızını ayarlama

- Işaretleyerek okuma etkinlikleri: Konu çerçevesinde makalede önemsenen kişileri ve katkılarını belirleme; makalede geçen çelişkili ifadeleri saptama. 
- Esnek ve seçmeli okuma etkinlikleri: Konu çerçevesinde makalede öne çıkarılan kavramları ve günlük yaşama olan katkılarını belirleme; makalenin bağlamı doğrultusunda yazar ve gönderimde bulunduğu kişilerin ortaklaştı̆̆ noktaları belirleme.

Önemli bilginin velveya anahtar noktaları altını çizme veya yuvarlak içine alma

- Seçmeli okuma etkinlikleri: Makalede yazar tarafından gönderimde bulunulan kişinin, konu bağlamında önemsenen düşünce ve katkılarını bulma; makalede yazar tarafindan üzerinde yoğunlaşılan kavramların günlük yaşama olan katkılarını bulma.

- Işsaretleyerek okuma etkinlikleri: Makalede, yazar ve farklı kişilerce ileri sürülen düşünceleri saptama.

- Esnek okuma etkinlikleri: Makale türüne özgü kullanımları belirleme.

Anlamayı artırmak için sözlük, genel ă̆ gibi başvuru kaynaklarını kullanma

- Not alarak okuma ve metinlerle ilişkilendirme etkinlikleri: Makalede, yazar tarafindan görüşleri önemsenen kişinin, konu bağlamındaki diğer özdeyişlerini öğrenebilmek amacıyla sözlük vb. başvuru kaynaklarından yararlanma ve bunları not etme; benzer anlamlara sahip anahtar sözcüklerin ilişkilerini belirlemek amaciyla sözlük vb. başvuru kaynaklarından yararlanma.

Metin zor geldiğinde üzerinde iyice yoğunlaşma

- Eleştirel okuma etkinlikleri: Makalede geçen karmaşık ve çelişkili noktaları saptama ve çözümleme; makalenin temel/ana düşüncesini bulma; makalede ileri sürülen tez, görüş, inanç ve varsayımları saptama; makalede ileri sürülen tez, görüş, inanç ve varsayımların sunuluş biçimlerini ve geliştirilme yollarını belirleme.

- Esnek okuma etkinlikleri: Makalenin üzerine yoğunlaştığı konu ve tartışmayı saptama; makalenin yazılış amacını belirleme.

Okuduğunu kavramaya yardımcı olması için gerekirse yüksek sesle okuma

- Işaretleyerek okuma etkinlikleri: Makalede geçen karmaşık ve çelişkili noktaları belirleme.

- Seçmeli okuma etkinlikleri: Makalede ileri sürülen tez, görüş, inanç ve varsayımları saptama; makalede ileri sürülen tez, görüş, inanç ve varsayımların sunuluş biçimlerini ve geliştirilme yollarını belirleme.

- Esnek okuma etkinlikleri: Makalede üzerinde yoğunlaşılan konu ve kavramları saptama.

Zaman zaman durarak okuduklarını denetleme

- Esnek okuma etkinlikleri: Makalede üzerinde yoğunlaşılan konu ve kavramları saptama.

- Eleştirel okuma etkinlikleri: Makalede ileri sürülen tez ve görüşlerin sunuluş biçimlerini ve geliştirilme yollarını bulma; makalede geçen çelişkili noktaları makalenin genel bağlamı doğrultusunda çözümleme ve değerlendirme; makalenin yan düşüncelerini çıkarma; makalede ileri sürülen tez ve görüşleri saptama ve günümüz koşulları ile karşılaştırarak değerlendirme; makale türüne özgü kullanımları saptama ve doğrulama.

\section{Bağlama yönelik ipuçlarını kullanma}

- Eleştirel okuma etkinlikleri: Makalede geçen çelişkili noktaları çözümleme ve değerlendirme; makalenin temel/ana/ortak düşüncesini çıkarma; makalede ileri sürülen tez, görüş, inanç ve varsayımları saptama ve değerlendirme; makalede ileri sürülen tez, görüş, inanç ve varsayımların sunuluş biçimlerini ve geliştirilme yollarını bulma; bağlamdan yola çıkarak anahtar sözcüklerin anlamlarını ve kullanım amaçlarını kestirme; makalede geçen sözcükleri bağlamına uygun olarak kendi tümceleriyle ifade etme; makalede geçen sözcükleri günlük yaşamdaki kullanımlarıyla ilişkilendirme.

- Esnek okuma etkinlikleri: Metin türüne özgü kullanımları saptama. 
Bilginin akılda kalıcılı̆̆ın sağlamak için onu şema, resim gibi görsellerle formülleştirme

- Eleştirel okuma etkinlikleri: Makalenin üstyapısal özelliklerine ilişkin çıkarımlarda bulunup şemalaştırma; makalenin planını çıkarma.

Noktalama işaretlerine, kalın ve italik yazımlara dikkat etme

- Tartışarak okuma etkinlikleri: Farklı yazımlara dikkat ederek makalede ileri sürülen tezlere ve görüşlere ulaşma; farklı yazımlara dikkat ederek makalenin yapı özelliklerine ilişkin çıkarımda bulunma.

Metinde çelişkili bir bilgiyle karşılaşınca metni tekrar gözden geçirme

- Esnek okuma etkinlikleri: Makalenin kimi bölümlerinde var olan çelişkili ifadeleri saptama ve çözümleme.

- Eleştirel okuma etkinlikleri: Makalede geçen çelişkili bir bilgiyi, metnin genel çerçevesi ve ana düşüncesi bağlamında değerlendirme.

Anlamı bilinmeyen sözcük ve sözcük öbeklerini bağlam içinde tahmin etmeye çalışma

- Eleştirel okuma etkinlikleri: Altı çizili olarak verilen sözcüklerin anlamlarını bağlamdan yola çıkarak kestirme ve tümce oluşturma; anlamı verilen sözcükleri bağlamından hareketle bulma.

- Seçmeli okuma etkinlikleri: Altı çizili olarak verilen sözcük ve sözcük öbeklerinin tümceye kattı̆̆ 1 anlamı seçme.

Metinde geçen karmaşık fakat önemli bilgi ve düşünceleri ayırt etme/özetleme

- Esnek okuma etkinlikleri: Makalede geçen karmaşı ve çelişkili noktaları saptama.

- Özetleyerek okuma etkinlikleri: Makalede vurgulanan ve öne çıkarılan konu ve görüşleri belirleyip özetleme; makale türüne özgü kullanımları belirleyip özetleme.

- Eleştirel ve işaretleyerek okuma etkinlikleri: Makalede sunulan görüş ve tezlerin kim (yazar, atıf yapılan kimse vb.) tarafından savunulduğunu belirleme.

\section{Dilbilgisel ilişkileri kestirme/Băglayıcıları tanıma}

- Eleştirel okuma etkinlikleri: Bağlayıcılardan yola çıkarak metinde geçen çelişkili bir bilgiyi saptama; dilbilgisel ilişkilerden ve bağlayıcılardan yola çıkarak makalede mantıksal ve kavramsal ilişkilerin nasıl kurulduğunu saptama; bağlayıcıların, bağlantı öğelerinin makale türündeki kullanım amaçlarını ve anlamlarını kestirme.

\section{Sözcükleri parçalama}

- Eleştirel okuma etkinlikleri: Sözcük ve sözcük öbeklerinin üretim biçimlerine (tarama, derleme, türetme vb.) karar verme; sözcügün üretim biçiminden yola çıkarak anlamını kestirme; benzer anlamlar taşıyan yabancı ve Türkçe sözcüklerin anlamlarını sözlük vb. başvuru kaynaklarından yararlanarak bulma.

\section{Sözcükleri sinıflandırma}

- Işsaretleyerek okuma etkinlikleri: Kutu içerisinde verilen sözcük ve sözcük öbeklerini, üretim biçimlerine (tarama, derleme, birleştirme vb.) göre sınıflandırma.

- Eleştirel okuma etkinlikleri: Makale türünde sıkça kullanılan ve bağlam içerisinde sunulan bağlayıcıları, bağıntı öğelerini anlamsal olarak sınıflandırıp eşleştirme.

\section{Sözcükleri ilişkilendirme}

- Işsaretleyerek okuma etkinlikleri: Metinden yola çıkarak anahtar sözcükle ilişkili kavramları bulma. 
- Tartışarak okuma etkinlikleri: Metnin anahtar sözcükleri arasında ilişki kurup anlamsal benzerlik ve farklılıklarını tartışma.

\section{Etkinleştirilen biçimsel şemadan/tür bilgisinden yararlanma}

- Seçmeli okuma etkinlikleri: Makalede savunulan tez, düşünce, inanç ve varsayımları çıkarma; makalede kullanılan düşünceyi geliştirme yollarını ve anlatım biçimlerini bulma; makalede ileri sürülen düşünce, tez, inanç ve varsayımların sunuluş ve destekleniş biçimlerini belirleme.

- Işsaretleyerek okuma etkinlikleri: Makalede ileri sürülen düşünce, tez, inanç ve varsayımların kim tarafından savunulduğunu ve/veya reddedildiğini saptama; makalede mantıksal ve kavramsal ilişkilerin hangi bağlayıcılar ve/veya önermeler aracılığıyla kurulduğunu bulma.

- Esnek okuma etkinlikleri: Makalede üzerinde yoğunlaşılan kişi, nesne ve kavramları saptama.

- Özetleyerek okuma etkinlikleri: Makalenin planını çıkarma.

- Eleştirel okuma etkinlikleri: Makalede yazarın niyetini sorgulama; makalenin hangi tartışma üzerine konumlandığını belirleme; makalede okur ile kurulan iletişim biçimini saptama.

- Not alarak okuma etkinlikleri: Makalenin üstyapısal özelliklerine ilişkin çıkarımlarda bulunma.

Metinle ilgili önceki sorularını yeniden inceleme ve düzeltme

- Soru sorarak okuma etkinlikleri: Okuma öncesi oluşturulan soruların, metnin içerisinden yanıtlarını bulma ve yazma.

Metindeki önemli bilgilere diğer bilgilerden daha çok dikkat kesilme veya ileriye ya da geriye dönük sıçramalar yapma

- Seçmeli ve esnek okuma etkinlikleri: Makalede üzerine yoğunlaşılan noktaları belirleyip günlük yaşama olan olumlu ve olumsuz katkılarını saptama.

- Işsaretleyerek okuma etkinlikleri: Yazarın çelişkilerini saptama; makalede üzerine yoğunlaşılan düşünce ve tezlerin kim tarafından savunulduğunu bulma.

- Eleştirel okuma etkinlikleri: Makalenin üstyapısal özelliklerine ilişkin çıkarımlarda bulunma; makalede koyu yazı biçimiyle ifade edilmiş yargı tümcelerinin içerikle olan ilişkisini sorgulama.

\section{Her bir paragrafin ana fikrini tahmin etme}

- Seçmeli ve özetleyerek okuma etkinlikleri: Makalede farklı kişilerce ileri sürülen tez ve görüşleri belirleyip özetleme.

- Eleştirel okuma etkinlikleri: Makalede koyu yazı biçimiyle ayrılmış bölümlerde ileri sürülen temel düşünceye karar verme.

Yeni bilgilerle önceki bilgileri ilişkilendirme, çăgrışım oluşturma

- Eleştirel okuma etkinlikleri: Makalede ileri sürülen bir düşünceyi önceki bilgilerinden ve günlük yaşamdaki deneyimlerinden yola çıkarak değerlendirme; makalenin konusu bağlamında günlük yaşamda gözlemlenen olumlu ve olumsuz durumları belirleyip eleştirme.

- Metinlerle ilişkilendirme etkinlikleri: Okunan makaleden bağımsız olarak verilen aynı türdeki bir metinden yola çıkarak karşılaştırmalar yapma ve makale türüne özgü kullanımları belirleme; diğer metin türlerine özgü bilgilerden de yararlanarak makale türüne özgü kullanımları belirleme; farklı tür özelliklerine sahip iki metni (öykü ve makale) biçimsel ve içerik olarak karşılaştırma, türüne karar verme. 
Başlık, okuma ilerledikçe alt başlık, görsel çizimler vb. öğelerden yararlanarak metnin iletisini kestirme ve onaylama

- Eleştirel okuma etkinlikleri: Makalede farklı kişilerce ileri sürülen tez ve görüşleri belirleyip metnin ana/temel/ortak düşüncesini saptama; başlık, görseller, anahtar sözcükler ve vurgulanan ifadelerden yola çıkarak yazarın niyetini ve öne çıkardığı temel düşünceyi sorgulama; okuma sırasında yan düşüncelere ilişkin edinilen çıkarımlar ile koyu yazılmış olarak özetlenen yargıları karşılaştırıp makalenin temel/ana düşüncesine karar verme.

\section{Okuduklarını arkadaşlarıyla tartışma}

- Tartısarak ve soru sorarak okuma etkinlikleri: Okuma öncesinde sorulan soruların yanıtlarına ilişkin arkadaşlarıyla tartışma ve uygun yanıta karar verme; makalede ileri sürülen tez ve görüsslere ilişkin oluşturulan tümceleri, arkadaşlarıyla ve makalede koyu yazılmış ifadelerle karşılaştırıp benzerlik ve farklılıklarına yönelik tartışmalar yapma; metnin temel/ana düşüncesiyle ilişkili olarak makalede başvurulan düşünceyi geliştirme yollarına ilişkin örnekleri belirleyip işlevlerini arkadaşlarıyla tartışma.

- Eleştirel okuma etkinlikleri: Makalenin temel/ana düşüncesinin doğruluğuna ilişkin günümüz koşullarını da dikkate alarak değerlendirmeler yapma; makalenin temel/ana düşüncesinin günümüzdeki geçerliğine ilişkin olumlu-olumsuz gözlem ve deneyimlerini arkadaşlarıly paylaşma ve karar verme.

\section{Tartışma/Sonuç ve Öneriler}

Okurun, amacı doğrultusunda seçtiği metni anlamlandırabilmesi için metin türüne özgü bir okuma gerçekleştirmesi gerekir. Bu düşünce bağlamında araştırmada öykü, şiir ve makale türlerine uygun üstbilişsel okuma sırası stratejileri ile okuma yöntem-teknikleri ilişkilendirilmiş ve bu ilişkiyi temel alan okuma eğitimi kapsamında gerçekleştirilebilecek okuma sırası etkinlikleri önerilmiştir.

Bulgular sonucu her üç türde de eleştirel okumanın ağırlıklı olarak kullanıldığ 1 görülmektedir. Yazınsal metinler imge kullanımını anlamlandırmayı ve yüzeysel yapıdan yola çıkarak derin yapıdaki iletiye ulaşmayı hedefler. Bilgilendirici metinler ise önceki bilgilerle yapılandırılır. Bu nedenle iki farklı metin tipi de eleştirel okumayı gerektirir. Bunun dışında, öyküde daha çok tahmin ederek, özetleyerek ve metinlerle ilişkilendirerek; şiirde esnek, yaratıcı ve metinlerle ilişkilendirerek; makalede ise işaretleyerek, seçmeli ve esnek okumanın kullanıldığı görülmektedir (bk. Tablo 4).

Tablo 4.

Metin Türlerine Uygun Okuma Yöntem-Teknikleri

\begin{tabular}{|c|c|c|c|c|c|c|c|c|c|}
\hline $\begin{array}{l}\text { Metin } \\
\text { Türleri }\end{array}$ & $\begin{array}{c}\text { Eleştirel } \\
\text { okuma }\end{array}$ & $\begin{array}{l}\text { Tahmin } \\
\text { ederek } \\
\text { okuma }\end{array}$ & $\begin{array}{c}\text { Özetleye } \\
\text {-rek } \\
\text { okuma }\end{array}$ & $\begin{array}{l}\text { Metinlerle } \\
\text { iliş̧kilendir } \\
\text {-me }\end{array}$ & $\begin{array}{c}\text { Esnek } \\
\text { okuma }\end{array}$ & $\begin{array}{l}\text { İşaretleye- } \\
\text { rek okuma }\end{array}$ & $\begin{array}{c}\text { Seçmeli } \\
\text { okuma }\end{array}$ & $\begin{array}{l}\text { Yaratic1 } \\
\text { okuma }\end{array}$ & $\begin{array}{l}\text { Görsel } \\
\text { okuma }\end{array}$ \\
\hline \multicolumn{10}{|l|}{ Öykü } \\
\hline Makale & & & & & & & & & \\
\hline
\end{tabular}

Yazınsal metinler, özleri gereği diğer metin türlerinden farklı yollarla alımlanır (Polat, 2006, s. 20). Bu nedenle araştırmada, öykü ve şiirin; "metindeki grafik, tablo ve resim gibi kavramlardan yararlanma" dışında ortak üstbilişsel okuma sırası stratejilerini gerektirdikleri görülmüştür. Benzer bir biçimde her iki türde de yaşamla ilişkilendirme bağlamında eleştirel ve metinlerle ilişkilendirme okuma yöntem-teknikleri kullanılmaktadır. Yazınsal metinlerde yazar tarafından okurun kendi artalan bilgisiyle ve yaşantısıyla dolduracağı anlamsal boşluklar bırakılır. Bu anlamsal boşluklar, farklı veya aynı okurlarca farklı zamanlarda okunduğunda farklı anlamlar kazanır, dolayısıyla yazınsal metinler çokanlamlıdır. Yazınsal bir metin türü olan öykü okunurken de aynı süreç işletilir; bu tür bir okuma, günlük yaşamla ilişkilendirilir ve yazar tarafından sonuç, yoruma açık bırakıldığı için eleştirel okuma gerçekleşir. 
Şiir ise duyguya dayalı bir türdür. Bu türde, estetik yapı ve dilin kullanımı önemlidir. "Özellikle şiirde şairler gündelik dilin söz birimlerini birtakım sapmalar ve bağdaştırmalarla yeni anlamlar ya da çağrışımlar oluşturacak biçimde kullanırlar" (Özdemir, 1993, s. 22-23). Bu nedenle şiir türünde öncelikle bilinmeyen sözcüklerin anlamını bulma, anlamı bilinmeyen sözcük ve sözcük öbeklerini bağlam içinde tahmin etmeye çalışma, dilbilgisel ilişkileri kestirme/bağlayıcıları tanıma, yazınsal araçlar ya da retorik stratejiler gibi metne özgü özellikleri tanıma, sözcükleri parçalama, sınıflandırma ve ilişkilendirme gibi sözcüklerin anlamsal yapılarını, çağrışımlarını, söz sanatlarını vb. yazınsal araçlarını ortaya çıkaracak üstbilişsel okuma stratejilerini, buna bağlı olarak da eleştirel okuma yöntemini işletmek gerekmektedir. Bir şiir okunurken sözün ve şiirsel söylemin kavranması, imge örüntüsünün ortaya çıkarılması vb. noktaların yanı sıra şiirin kişisi kimdir, şiir kişisi kime seslenmektedir, şiirin yazılmasına yol açan durum nedir, şiirde anlatılanlar nerede, ne zaman, nasıl bir ortamda oluşmuştur, şiirin yazılış nedeni nedir, şiirdeki baskın ton nedir gibi sorulara da yanıt aranması gerekmektedir (Özdemir, 2002). Bu bağlamda, zaman zaman durarak okuduklarını denetleme, bağlama yönelik ipuçlarını kullanma gibi eleştirel okumayı gerektiren üstbilişsel okuma stratejileri kullanılmalıdır.

Bilgilendirici metin türlerinden biri olan makalede düşünceleri geliştirmek, desteklemek, kanıtlamak için verilen örneklerden yararlanılarak savunulan ve/veya reddedilen düşünceler ele alınır (Beyreli, Çetindağ ve Celepoğlu, 2008, s. 130-132). Okurlardan beklenen ise metne önyargısız ve yansız bir tutumla yaklaşmaları, metni çözümledikten sonra eleştirel bir yaklaşımla onu değerlendirmeleridir (Adalı, 1993, s. 65-68). Bu tür okuru, okuduklarını denetleme; bağlama yönelik ipuçlarını kullanma; bilgiyi şema, resim gibi görsellerle formülleştirip özetleme; çelişkili, karmaşık ve önemli bilgileri ayırt etme; bilinmeyen sözcük ve sözcük öbekleriyle çalışma; dilbilgisel ilişkileri ve bağlayıcıları kestirme; ana düşünceyi bulma; başlık, alt başlık vb. öğelerden yararlanma; tür bilgisini işletme; eski ve yeni bilgileri ilişkilendirme ve okunanları arkadaşlarıyla tartışma gibi üstbilişsel okuma sırası stratejilerini kullanmaya yönlendirdiği için ağırlıklı olarak eleştirel okuma yöntemini işletmeyi gerektirmektedir.

Her üç türde eleştirel okumanın ortak kullanımıyla birlikte; yazınsal metin türlerinden şiir yoğun anlamsal yapılara odaklanarak esnek okumayı; öykü ise içinde bir olay barındırdığ için özetleyerek okumay1, görsellerle sunulduğu için görsel okumayı da gerektirir. Öykü türünde yeni bilgilerle eski bilgilerin ilişkilendirilmesi; durum ve olayların nedeninin çok az sayıda sözcük ile anlatılması sonucu çıkarımlarda bulunulması ve simgesel kullanımların derin yapıda anlamlandırılması için bağlama yönelik ipuçlarının kullanılması gerektiğinden tahmin ederek okuma kaçınılmazdır. Sözcük öbekleri ve tümceler bağlamında bir yoğunluk, sözcük seçiminde de bir baskınlık söz konusu olduğundan sözcükleri ilişkilendirme, sınıflandırma ve yazınsal araçlar ya da retorik stratejileri anlamlandırma söz konusudur. Ayrıca, anlatıların özellikle konum bölümünde bulunan yer, zaman, kişiler, gerçekleşecek olayların tarihsel ve sosyal bağlamdaki önbilgileri için yapılan betimlemeler gösterimsel imge oluşturulmasını sağlar. Tüm bu nedenler okuru özetleyerek ve eleştirel okumaya yönlendirir. Öykünün planı yüzeyde gerçekçi; ancak derin yapıda mitlere yönelik, düşsel ve şiirsel olduğu için (Erden, 1998) metinlerle iliskilendirerek okumalara da ortam hazırlamaktadır.

Şiir okuma sürecinde; etkinleştirilen biçimsel şemadan/tür bilgisinden yararlanma, yeni bilgilerle önceki bilgileri ilişkilendirme, çağnışım oluşturma, gösterimsel imge oluşturma gibi üstbilişsel okuma stratejilerinin kullanımı da anlamsal katmanların ortaya çıkartılmasında etkili olmaktadır. Dolayısıyla bu türün anlamlandırılmasında eleştirel okumanın yanı sıra esnek okuma, yaratıcı okuma ve metinlerle ilişkilendirme gibi okuma yöntem-teknikleri de işletilmektedir.

Eleştirel bir okuma süreci gerektiren makale türünde aynı zamanda önemli, ilgi çekici ya da aranan bilgiye ilişkin işaretlemeler yapma; bu bağlamda okuma hızında değişikliklere gitme; kavramayı artırmak için yüksek sesle okuma; okuma amacına göre gerekli bilgileri bulgulama ve yinelemeli okumalar yapma gibi işlemlere (Ontario, 2004, s. 82) başvurulduğundan esnek, işaretleyerek ve seçmeli okuma yöntem-teknikleri de işe koşulur. Not alma; okunanlar üzerine 
tartışma; ileri sürülen tez ve düşünceleri özetleme; anlamayı artırmak için farklı kaynaklara başvurma; metinle ilgili önceki sorularını yeniden inceleme ve düzeltme stratejilerinin de makale okurken kullanılması nedeniyle not alarak, tartışarak, özetleyerek, soru sorarak ve metinlerle ilişkilendirme okuma yöntem-tekniklerinden de destekleyici olarak yararlanılabilir.

Bilgilendirici metinlerde, yazınsal metinlerden farklı olarak birden çok şematik yapı kullanılabilir. Bu tip metinler okunurken metin türünün ayrımına varıp o metin türüne uygun okuma amacı belirleme, konuyla ilgili artalan bilgilerini kullanma, metnin şematik ve anlamsal yapısı (tekanlamlılı) ile mantıksal örüntülerinin ayrımına varma gibi işlemlere başvurulur (Ülper, 2010, s. 13). Meyer (1985), bilgilendirici metinlerdeki şematik yapıları açıklama, sıralama, neden-sonuç, sorun-çözüm ve karşılaştırma olarak belirlemiştir. Belirlenen yapılar, farklı üstbilişsel okuma sırası stratejilerini, dolayısıyla farklı okuma yöntem-tekniklerini kullanmayı gerektirir. Bu bağlamda araştırmada, makale türü için ağırlıklı olarak eleştirel, işaretleyerek, esnek ve seçmeli okuma yöntem-tekniklerinin; yanı sıra not alarak, soru sorarak, tartışarak, özetleyerek ve metinlerle ilişkilendirme okuma yöntem-tekniklerinin kullanıldığ görülmüştür.

Araştırma kapsamındaki metin türleri için üstbilişsel okuma sırası stratejileri ve okuma yöntem-teknikleri bağlamında başka farklılaşmalar da bulunmaktadır. Örneğin, makale ve şiir türlerinde esnek okuma yöntem-tekniği yoğunlaşmıştır. Bunun nedeni olarak şiirde imge kullanımının ve dış yapı özelliklerinin, makalede ise üstdil kullanımının etkinliğinden söz edilebilir. Bununla birlikte makale seçmeli okumayı gerektirir; çünkü bilgilendirici metinlerde anlam, yazınsal metinlerde olduğu gibi metnin bütününe yayılmamıştır; okuma amacına göre metnin bir bölümünde bulunabilir.

Aynı üstbilişsel okuma sırası stratejilerinin metin türlerine göre farklı okuma yöntemtekniklerini gerektirdiği de görülmüştür. Örneğin, bilinmeyen sözcüklerin anlamını bulma stratejisini gerçekleştirmek için öyküde tahmin ederek, eleştirel, metinlerle ilişsilendirme; şiirde eleştirel; makalede ise seçmeli okuma yöntemi kullanılmıştır. Zaman zaman durarak okuduklarını denetleme stratejisi, genelde üç tür için de eleştirel okumayı gerektirirken öyküde özetleyerek, makalede esnek okuma da gerçekleştirilmiştir. Bağlama yönelik ipuçlarını kullanma stratejisinde ise eleştirel okumanın yanı sıra öyküde tahmin ederek, özetleyerek ve yaratıcı okuma yapılırken şiir ve makalede genellikle esnek okuma gerçekleştirilmiştir. Anlamı bilinmeyen sözcük ve sözcük öbeklerini bağlam içinde tahmin etmeye çalışma okuma stratejisi, üç türde de eleştirel okumayı temel alırken öyküde tahmin ederek, makalede ise seçmeli okuma yöntem-teknikleri de kullanılmıştır. Etkinleştirilen biçimsel şemadan/tür bilgisinden yararlanma stratejisi için öyküde tahmin ederek, eleştirel, özetleyerek, yaratıcı ve görsel; şiirde esnek; makalede ise not alarak, işaretleyerek, eleştirel, seçmeli, esnek ve özetleyerek okuma yöntemteknikleri kullanılmıştır. Bununla birlikte aynı okuma yöntem-tekniklerini gerektiren stratejiler de yer almaktadır. Örneğin, her üç türde de yeni bilgilerle önceki bilgileri ilişkilendirme/çağrışım oluşturma stratejisi için metinlerle ilişkilendirme temel okuma biçimidir. Ayrıca öyküde tahmin ederek, eleştirel ve yaratıcl; makalede eleştirel okuma da kullanılmıştır.

Dilbilgisel ilişkileri kestirme/bağlayıcıları tanıma, sözcükleri parçalama ve sınıflanlandırma gibi dilsel yetilerle ilgili stratejiler her metin türü için eleştirel okumayı gerektirmiştir; ancak dil kullanımı ile bağdaştırılacak sözcüklerle ilişkilendirme stratejisinde türler, okuma yöntem-teknikleri bağlamında farkl1lık göstermektedirler. Öykü tahmin ederek, eleştirel, özetleyerek ve metinlerle ilişkilendirme; şiir eleştirel; makale ise işaretleyerek ve tartışarak okumayı gerekli kılmaktadır.

Çalışmada metin türlerine uygun üstbilişsel okuma sırası stratejileri ile okuma yöntemtekniklerinin ilişkilendirilmesiyle hazırlanan etkinlikler, öneri niteliğinde olup uygulamalı çalışmalarla genellenebilirliğinin artırılacağı düşünülmektedir. Araştırmanın sonuçları ve sonuçlara iliş̧in tartışmaların konu ile ilgili farklı çalışmalara kılavuzluk edeceği ve Türkçe öğretim ortamlarındaki uygulama sürecine katkı sağlayacağı öngörülmektedir. 


\section{Kaynaklar}

Adalı, O. (1993). Bilgilendirici metinlerin okunması. J. Baysal, N. İpşiroğlu, Z. İpşiroğlu ve Ş. Ozil, (Yay. haz.). Yaratıcı Toplum Yolunda Çağdaş Ĕgitim (3. Baskı) içinde (ss. 61-70). İstanbul: Cem Yayınevi, Çağdaş Yaşamı Destekleme Derneği Yayınları 1.

Anderson, L. W., Krathwohl, D. R., Airasian, P. W., Cruikshank, K. A., Mayer, R. E., Pintrich, P. R, Raths, J. ve Wittrock, M. C. (2014). Ögrrenme ögrretim ve değerlendirme ile ilgili bir sınıflama: Bloom'un eğitim hedefleri ile ilgili sınıflamasının güncelleştirilmiş biçimi (2. Bask1). D. A. Özçelik (Çev.). Ankara: Pegem Akademi Yayıncılık.

Aydın-Gönül, D. (2016). Türkçe ders kitaplarındaki yazınsal metinleri okuma-anlama etkinliklerinin eleştirel okuma ölçütlerini karşılama yeterliliği (8.sınıf örneği) (Yayımlanmamış yüksek lisans tezi). İstanbul Üniversitesi, Eğitim Bilimleri Enstitüsü, İstanbul.

Aydın, S. ve Demir-Atalay, T. (2015). Öz-düzenlemeli öğrenme. Ankara: Pegem Akademi Yayıncilik.

Bamberger, R. (1990). Okuma alışkanlı̆̆ını geliştirme. B. Çapar (Çev.). Ankara: Kültür Bakanlığı.

Beyreli, L., Çetindağ, Z. ve Celepoğlu, A. (2008). Yazılı ve sözlü anlatım (3. Baskı). Ankara: Pegem Akademi Yayıncılık.

Bohn-Gettler, C. M. ve Kendeou, P. (2014). The interplay of reader goals, working memory, and text structure during reading. Contemporary Educational Psychology, 39, 206-219.

Creswell, J. W. (2014). Araştırma deseni (4. Baskı) (Y. Dede, Çev.). Ankara: Eğiten Kitap.

Çetinkaya-Edizer, Z., Dilidüzgün, Ş., Ak-Başoğul, D., Karagöz, M. ve Yücelşen N. (2018). Türkçe öğretiminde üstbilişsel okuma stratejileri ile okuma yöntem-tekniklerinin metin türüne göre değerlendirilmesi. Adlyaman Üniversitesi Sosyal Bilimler Enstitüsü Dergisi, 10(29), 479-511.

Dilidüzgün, Ş. (2013). Ortaokul Türkçe derslerinde oku(ma)dan özet yaz(ma)ya. Ankara Üniversitesi Eğitim Bilimleri Fakültesi Dergisi, 46(2), 47-68.

Dilidüzgün, Ş., Çetinkaya-Edizer, Z., Ak-Başoğul, D., Karagöz, M. ve Yücelşen, N. (2018, Haziran). Metin türüne uygun okuma becerisini geliștirmeye yönelik okuma yöntem teknikleriyle üstbilişsel okuma stratejilerini ilişkilendirme çalışması [Öz]. ERPA International Congresses on Education'da sunulan bildiri, İstanbul Üniversitesi, İstanbul.

Erden, A. (1998). Kısa öykü ve dilbilimsel eleştiri. Ankara: Gündoğan Yayınları.

Erözden, A. (1998). Okuma dersinin değişik boyutları. İstanbul Üniversitesi, Yabancı Diller Eğitimi Bölümü Dergisi, YDEB II, 29-58. İstanbul: Çantay Kitabevi.

Flavell, J. ve Wellman, H. (1977). Metamemory. Jr. R. V. Kail ve J. Hagen (Yay. haz.). Perspectives on The Development of Memory and Cognition içinde (ss. 3-33). Hillsdale, NJ: Erlbaum.

Göktürk, A. (1989). Çeviri: Dillerin dili. İstanbul: Çağdaş Yayınları.

Grabe, W. (2002). Narrative and expository, macro-genres. A. M. John (Yay. haz.). Genre in The Classroom: Multiple perspectives içinde. USA: Lawrence Erlbaum Associates.

Karatay, H. (2014). Okuma eğitimi-kuram ve uygulama (2. Bask1). Ankara: Pegem Akademi Yayınc1lik.

Kim, M. (2006). Genre-based approach to teaching writing. TESL Working Paper Series, 4(2), 33-39.

Langer, J. A. (1990). The process of understanding: reading for literary and informative purpose. Research in the Teaching of English, 24(3), 229-260.

MEB. (2018). Türkçe dersi öğretim programı (Illkokul ve ortaokul 1, 2, 3, 4, 5, 6, 7 ve 8. sinuflar). Ankara: MEB Yayınları.

Meyer, J. B. F. (1985). Prose analysis: Purposes, procedures, and problems. B. K. Britten ve J. B. Black (Yay. haz.). Understanding Expository Text: A Theoretical and Practical Handbook for Analyzing Explanatory Text içinde (ss. 11-64). Hillsdale, NJ: Erlbaum. 
Ontario, Ministry of Education. (2004). Think literacy: Cross-curricular approaches, grades 7 12. Erişim adresi: http://www.edu.gov.on.ca/eng/studentsuccess/thinkliteracy/files/Think LitEnglish10-12.pdf

Özdemir, E. (1983). Okuma sanatı. İstanbul: İnk1lap Kitabevi.

Özdemir, E. (1992). Sözlü ve yazılı anlatım tekniği, kompozisyon. İstanbul: Remzi Kitabevi.

Özdemir, E. (1993). Dil edebiyat öğretiminde yeni yönelimler. B. Özer (Yay. haz.), Türk Dili ve Edebiyatı Öğretimi içinde (ss. 12-30). Eskişehir: Anadolu Üniversitesi Açıöğretim Fakültesi.

Özdemir, E. (2002). Eleştirel okuma (5. Basım). Ankara: Bilgi Yayınevi.

Paltridge, B. (2001). Genre and the language learning classroom. The University of Michigan Press.

Polat, T. (2006). Okur odaklı bir yaklaşımla yazın eğitimi. Milli Eğitim Edebiyat Ĕgitimi ve Öğretimi Özel Saylsı, 34, 169.

Sever, S. (2013). Çocuk edebiyatı ve okuma kültürü. İzmir: Tudem.

Shokouhi, H. ve Jamali, R. (2013). Metacognitive reading strategies and the text type. Shahid Beheshti University. Deakin University's Research Repository.

Ülper, H. (2010). Okuma ve anlamlandırma becerilerinin kazandırılmast. Ankara: Nobel Yayın Dağıtım.

Wellek, R. ve Warren, A. (1982). Yazın kuramı. Y. Salman, ve S. Karantay (Çev.). İstanbul: Altın Kitaplar Yayınevi.

\section{Extended Abstract}

\section{Introduction}

Thinking and sensitive people that democratic societies need are the people who have acquired reading culture (Sever, 2013). It is possible for individuals to win this culture by having their memory promoted in school type learning and entering into a cognitive process based on inventions. This process; it is a high-level cognitive process that requires analysis, interpretation, synthesis, and effective application of metacognition. Effective reading education also requires the operation of metacognitive reading strategies. Individuals are expected to read the text with reading method-techniques that they can use appropriate metacognitive reading strategies in line with their reading objectives. Readers are directed to different types of texts in line with their reading purposes and operate their reading strategies through the structural features of the text.

According to this theoretical framework, when the studies in the literature were examined, it was determined that the text type was not taken as the basis of the reading methodtechniques (Dilidüzgün, 2013), and the prepared activities were not designed to promote high level cognitive skills (Aydın-Gönül, 2016). It is also found that metacognitive reading strategies are not associated with reading method-techniques and the same metacognitive reading strategies and reading method-techniques are used in different text types, besides very few metacognitive reading strategies are targeted (Çetinkaya-Edizer, Dilidüzgün, Ak-Başoğul, Karagöz \& Yücelşen, 2018). This study the aim of which is to equip people with the ability to operate metacognitive reading strategies that are necessary to understand and interpret text types within the scope of reading education is based on the metacognitive while reading strategies, which is also called the stage of comprehension. In this direction, it is aimed to present the activity suggestions which require reading method-techniques to gain metacognitive while reading strategies specific to the text types.

\section{Method}

This study is a qualitative and descriptive research. In this study which aims to present activity suggestions by linking metacognitive while reading strategies and reading method-techniques in the context of text type along with the reading education, a table in the same context prepared by Dilidüzgün, Çetinkaya-Edizer, Ak-Başoğul, Karagöz and Yücelşen (2018) has been selected 
as a guide. In this table, the text types in Turkish Language Teaching Program (2018) are related with appropriate metacognitive while reading strategies and reading method-techniques. Therefore, which type of text requires which metacognitive while reading strategies and reading method-techniques are discovered and listed regarding the opinions of the experts.

In the literature, texts are classified under two subscales, usually literary and informative (Özdemir, 1992, p. 39; Ülper, 2010). In Turkish Language Teaching Program (MEB, 2018, p. 20 ), this classification is under three as narrative, informative and poetry. Based on this, the study focuses on stories, poetry and article as a result that they reflect the features of literary and informative text types and they are used frequently in textbooks. Therefore, criterion sampling was adopted from purposeful sampling methods.

In the study, firstly the literature was searched in order to determine the characteristics and distinctions of the stories, poems and article text types. After that, for each type, a text was selected from the textbooks and the text-based activities were prepared for each of them. While developing the activities on these texts, the reading method-techniques related to metacognitive while reading strategies that are appropriate for the story, poem and article text types mentioned in the table selected as a guide and the renewed taxonomy of Bloom (Anderson et al., 2014) are taken as the basis. The tables and activities created to show the reading method-techniques and metacognitive while reading strategies related to each activity have been sent to 3 field experts, 1 assessment-evaluation specialist and 1 Turkish teacher to consult their opinions. Necessary arrangements have been made in line with the evaluations received.

In order to increase the validity and reliability of the tables of specification, new activities were produced in accordance with the same approach and schedule on different texts selected from the textbooks, in line with the tables. It has been concluded that the activities and the tables prepared based on these recursive applications, which have been carried out with three text-oriented applications, are compatible. Thus, the validity and reliability of the tables of specification have been completed. At the end of the research, the activities have been presented under the headings of metacognitive while reading strategies and the subheadings of reading method-techniques specific to text types in the findings section.

\section{Result and Discussion}

As a result of these findings, it is seen that critical reading is used predominantly in all three types. The literary texts are taken in different ways from other types of texts according to their essence (Polat, 2006, p. 20). Therefore, in the research, it has been seen that story and poetry require common metacognitive while reading strategies except "the use of concepts such as graph, table and picture in the text". Similarly, in both types, in the context of relating to life, critical reading and the reading method of associating with texts are used. The article, which is one of the informative text types, discusses the ideas that are advocated and/or rejected by using the examples given to improve, support and prove the ideas (Beyreli, Çetindağ and Celepoğlu, 2008, pp. 130-132). This type requires critical reading as it directs readers to use the metacognitive reading order strategies such as using clues leading context; distinguishing contradictory, complex and important information; finding the gist and discussion with friends. With the common use of critical reading in all three types; the reading methods of predicting, summarizing and association with texts are used for stories; flexible, creative and associating with texts are used for poems and marking, elective, flexible, taking notes, discussing, summarizing, questioning and associating with texts are used for articles.

In the study, it has seen that the same metacognitive while reading strategies required different reading method-techniques according to the text types. For example, practicing the strategy of finding the meaning of unknown words requires predicting, critical, associating with the texts for the story; critical for poetry and elective reading methods for the article. While the strategy of monitoring what they read from time to time requires critical reading for three types in general, summarizing is used for the story and flexible reading is used for the article. In the strategy of using clues leading context, in addition to critical reading, the poem and the article generally include flexible reading while predicting, summarizing and creative reading are used 
for the story. While reading strategy, which is used to predict meaningless words and phrases in context, is based on critical reading in all three types, predictive reading method is also used for the story and elective reading method is used while reading the article. For the strategy of benefiting from the formal schema/species knowledge that is being activated, the reading methods of predicting, critical reading, summarizing, creative and visual reading are used for the story; flexible reading is used for poetry and taking notes, marking, critical, elective, flexible reading and summarizing are used for the article. However, there are also strategies that require the same reading method-techniques. For example, in all three types, associating with texts is the basic form of reading for the strategy of associating previous information with new information/association of ideas. In addition, predicting, critical and creative reading are also used for the story and critical reading for the article as well.

Strategies for linguistic abilities such as guessing grammatical relationships/recognizing binders, breaking and grouping words require critical reading for each type of text; however, in the strategy of correlating with words which can be associated with language use, text types differ in the context of reading method-techniques. Stories require the reading methods of predicting, critical reading, summarizing and association with texts; poetry requires critical reading and the article requires reading by marking and discussing.

In the study, the activities prepared by linking metacognitive while reading strategies and reading method-techniques appropriate to text types are considered as suggestions and it is thought that generalizability will be increased by applied studies. It is foreseen that the results of the study and the discussions about the results will guide different studies on the subject and contribute to the implementation process in Turkish language teaching environments. 